\title{
ANALISIS PERPUTARAN PIUTANG PADA PT. ADIRA DINAMIKA MULTI FINANCE
}

\author{
Suseno Hadi Purnomo \\ STIEM Bongaya Makassar \\ susenohadipurnomo73069@gmail.com
}

\begin{abstract}
ABSTRAK
Penelitian ini bertujuan untuk mengetahui tingkat perputaran piutang pada PT. Adira Dinamika Multi Finance. Metode analisis dalam penelitian ini dengan menggunakan analisis Perputaran Piutang (Receivable Turn Over), Periode Pengumpulan Piutang (Average Collection Period), Rasio Tunggakan dan Rasio Penagihan.

Berdasarkan hasil perhitungan perputaran piutang pada PT. Adira Dinamika Multi Finance, maka dapat diketahui bahwa semakin cepat pembayaran semakin baik bagi perusahaan,karena semakin cepat modal kerja yang tertanam dalam bentuk piutang kembali menjadi modal atau kas yang berarti semakin tinggi tingkat perputaran piutang.
\end{abstract}

Kata Kunci: Perputaran Piutang

\section{PENDAHULUAN}

\section{A. Latar Belakang}

Sebagaimana kita ketahui bahwa tujuan perusahaan yang paling utama adalah fokus pada pencapaian laba. Pencapaian laba yang tinggi dalam suatu perusahaan mengindikasikan bahwa perusahaan tersebut mampu menjalankan operasionalnya dengan baik. Hal tersebut dapat dilihat dari laporan kinerja perusahaan yaitu laporan laba rugi dan laporan neraca perusahaan. Namun demikian, masih banyak faktorfaktor lain yang tidak kalah penting menjadi sorotan dalam menilai tingkat efisiensi perusahaan yaitu perputaran piutang.

Ditengah persaingan bisnis yang ketat perusahaan dituntut untuk mampu meraih posisi pasar, sehingga perusahaan perlu melakukan strategi penjualan secara kredit, agar jumlah penjualan meningkat. Atas penjualan secara kredit maka perusahaan memiliki piutang kepada pelanggan. Tingkat penjualan tinggi tidak akan berarti apaapa apabila piutang tidak dapat ditagih. Oleh karena itu diperlukan pengelolaan piutang agar piutang berjalan dengan baik dan meminimalkan hal-hal yang mungkin terjadi diluar perhitungan. Piutang dapat menjadi potensi bila dikelola dengan baik tetapi sebaliknya akan menjadi resiko bila tidak dikelola dengan baik. Resiko kerugian piutang dapat berupa resiko tidak dibayarnya sebagian atau seluruh piutang, atau keterlambatan pelunasan piutang. Pengelolaan piutang memerlukan perencanaan yang matang, mulai dari penjualan kredit yang menimbulkan piutang sampai menjadi kas.

Dalam mengelola manajemen keuangan, khususnya mengenai piutang perlu direncanakan dan dianalisa secara seksama, sehingga kebijakan manajemen piutang dagang dapat berjalan secara efektif dan efisien, baik mengenai prosedur piutang, penagihan piutang, penjualan kredit dan masalah piutang lainnya.

Secara umum piutang timbul karena adanya transaksi penjualan barang atau jasa secara kredit. Ditengah persaingan bisnis yang ketat perusahaan dituntut untuk mampu meraih posisi pasar, 


\section{PAY Jurnal Keuangan dan Perbankan. Vol. 2 No. 2, Desember 2020}

sehingga perusahaan perlu melakukan strategi penjualan secara kredit, agar jumlah penjualan meningkat. Namun, konsekuensi dari kebijakan tersebut dapat menimbulkan peningkatan jumlah piutang, piutang tak tertagih dan biayabiaya lainnya yang muncul seiring dengan peningkatan jumlah piutang.

Dari latar belakang tersebut, penulis tertarik untuk melakukan suatu analisis tingkat perputaran piutang dagang pada pada PT. Adira Dinamika Multi Finance, sehingga dapat diketahui gambaran posisi atau keadaan piutang perusahaan yang sebenarnya agar perusahaan mampu mengetahui efektivitas dari pengelolaan piutangnya.

\section{B. Rumusan Masalah}

Berdasarkan latar belakang yang telah dikemukakan, maka rumusan masalah dalam penelitian ini adalah seberapa besar tingkat piutang pada PT. Adira Dinamika Multi Finance?

\section{Tujuan Penelitian}

Tujuan penelitian ini adalah untuk mengetahui tingkat piutang pada PT. Adira Dinamika Multi Finance.

\section{TINJAUAN PUSTAKA}

\section{A. Pengertian Piutang}

Soemarso (2009:338) piutang adalah piutang yang berasal dari penjualan barang atau jasa yang merupakan kegiatan usaha normal perusahaan, perusahaan mempunyai hak klaim terhadap seseorang atau perusahaan lain.

Hery (2013:181) menjelaskan piutang adalah sejumlah tagihan yang akan diterima oleh perusahaan umumnya dalam bentuk kas dari pihak lain.

\section{B. Faktor-Faktor Mempengaruhi Jumlah Piutang Bambang Riyanto (2010:85) faktor-faktor yang mempengaruhi jumlah piutang adalah sebagai berikut:}

1. Volume Penjualan Kredit

Makin besar jumlah penjualan kredit dari keseluruhan penjualan akan memperbesar jumlah piutang dan sebaliknya makin kecil jumlah penjualan kredit dari keseluruhan piutang akan memperkecil jumlah piutang.

2. Syarat Pembayaran Penjualan Kredit Semakin panjang batas waktu pembayaran kredit berarti semakin besar jumlah piutangnya dan sebaliknya semakin pendek batas waktu pembayaran kredit berarti semakin kecil besarnya jumlah piutang.

3. Ketentuan dalam Pembatasan Kredit Apabila batas maksimal volume penjualan kredit ditetapkan dalam jumlah yang relative besar maka besarnya piutang juga semakin besar.

4. Kebijakan dalam Pengumpulan Piutang

Perusahaan dapat menjalankan kebijaksanaan dalam pengumpulan piutang dalam 2 cara yaitu pasif dan aktif. Perusahaan yang menjalankan kebijaksanaan secara aktif dalam pengumpulan piutang akan mempunyai pengeluaran uang yang lebih besar dibandingkan dengan perusahaan lain yang menggunakan kebijaksanaanya secara pasif.

5. Kebiasaan Membayar dalam Pelanggan

Semua piutang yang diperkirakan akan terealisasikan menjadi kas dalam setahun di neraca disajikan dalam pada bagian aktiva lancar.

\section{METODE ANALISIS}

1. Perputaran Piutang (Receivable Turn Over)

Perputaran piutang merupakan rasio yang digunakan untuk mengukur berapa lama penagihan piutang selama satu periode. Atau berapa kali 


\section{PAY Jurnal Keuangan dan Perbankan. Vol. 2 No. 2, Desember 2020}

dana yang ditanam dalam piutang ini berputar dalam satu periode. Perputaran piutang disebut juga dengan RTO. Makin tinggi rasio menunjukkan bahwa modal kerja yang ditanamkan dalam piutang makin rendah dan tentunya kondisi ini semain baik bagi perusahaan. Sebaliknya jika rasio makin rendah, maka ada over investmen dalam piutang.

$$
\text { RTO }=\frac{\text { Penjualan kredit }}{\text { Piutang rata-rata }}
$$

2. Periode Pengumpulan Piutang (Average Collection Period)

ACP digunakan untuk mengetahui jangka waktu yang diperlukan untuk mengumpulkan piutang menjadi kas. Waktu perputaran piutang dinyatakan dalam hari, hal ini disebabkan syarat pembayaran yang ditetapkan didalam transaksi penjualan dinyatakan dalam satuan hari sebagai satuan waktu.

$$
\mathrm{ACP}=\frac{360}{\mathrm{RTO}}
$$

3. Rasio Tunggakan

Rasio tunggakan bertujuan untuk mengetahui berapa besar jumlah piutang yang telah jatuh tempo dan belum tertagih dari sejumlah penjualan kredit yang dilakukan.

Rasio Tunggakan $=\frac{\text { Piutang tak Tertagih }}{\text { Total Piutang }} \times 100 \%$

4. Rasio Penagihan

Rasio penagihan bertujuan untuk mengetahui berapa besar piutang yang tertagih dari total piutang yang dimiliki perusahaan.

$$
\text { Rasio Penagihan }=\frac{\text { Piutang tak Tertagih }}{\text { Total Piutang }} \times 100 \%
$$

\section{HASIL PENELITIAN}

A. Perputaran Piutang (Receivable Turn Over) pada PT. Adira Dinamika Multi Finance

Berdasarkan hasil perhitungan perputaran piutang (receivable turn over) pada PT. Adira Dinamika Multi Finance, maka dapat diketahui bahwa perputaran piutang mengalami fluktuasi selama lima tahun yaitu dari tahun 2015 sampai dengan tahun 2019, karena pada tahun 2015 perputaran piutang sebanyak 2.8 kemudian pada tahun 2016 naik sebanyak 9,4. Pada tahun 2017 perputaran piutang sebanyak 7,3 kemudian pada tahun 2018 sebanyak 5,34. Dan pada tahun 2019 perputaran piutangnya sebesar 3,9.

B. Periode Pengumpulan Piutang (Average Collection Period)

Berdasarkan hasil perhitungan periode pengumpulan piutang (average collection period) pada PT. Adira Dinamika Multi Finance, maka dapat diketahui bahwa periode pengumpulan piutang mengalami peningkatan selama lima tahun yaitu dari tahun 2015 sampai dengan tahun 2019, karena pada tahun 2015 periode pengumpulan piutang sebanyak 128 kemudian pada tahun 2016 sebesar 40. Pada tahun 2017 periode pengumpulan piutang naik sebesar 50, kemudian pada tahun 2018 sebanyak 72. Dan pada tahun 2019 sebesar 90.

\section{Rasio Tunggakan}

Berdasarkan hasil perhitungan rasio tunggakan yang diperoleh PT. Adira Dinamika Multi Finance, maka dapat diketahui bahwa rasio tunggakan mengalami peningkatan selama lima tahun yaitu dari tahun 2015 sampai dengan tahun 2019, karena pada tahun 2015 rasio tunggakan sebesar 16,85\%, kemudian pada tahun 2016 sebesar 


\section{PAY Jurnal Keuangan dan Perbankan. Vol. 2 No. 2, Desember 2020}

naik sebesar 10,22\%. Pada tahun 2017 rasio tunggakan naik sebesar $16,99 \%$, kemudian pada tahun 2017 juga naik sebesar 20,52\%. Dan pada tahun 2019 sebesar 20,84\%.

\section{Rasio Penagihan}

Berdasarkan hasil perhitungan rasio penagihan yang diperoleh PT. Adira Dinamika Multi Finance, maka dapat diketahui bahwa rasio penagihan mengalami kenaikan dan penurunan selama lima tahun yaitu dari tahun 2015 sebesar $83,15 \%$ sampai dengan tahun 2016 mengalami peningkatan sebesar $89,78 \%$, kemudian pada tahun 2017 turun sebesar $83 \%$ sampai dengan tahun 2018 sebesar 79,5\%. Dan pada tahun 2019 sebesar 79,16\%.

\section{KESIMPULAN}

Berdasarkan hasil penelitian ini, maka dapat disimpulan oleh peneliti sebagai berikut:

1. Berdasarkan hasil perhitungan perputaran piutang (receivable turn over) pada PT. Adira Dinamika Multi Finance, maka dapat diketahui bahwa perputaran piutang mengalami fluktuasi selama lima tahun yaitu dari tahun 2015 sampai dengan tahun 2019, semakin cepat pembayaran semakin baik bagi perusahaan,karena semakin cepat modal kerja yang tertanam dalam bentuk piutang kembali menjadi modal atau kas yang berarti semakin tinggi tingkat perputaran piutang.

2. Berdasarkan hasil perhitungan periode pengumpulan piutang (average collection period) pada PT. Adira Dinamika Multi Finance, maka dapat diketahui bahwa periode pengumpulan piutang mengalami fluktuasi yaitu dari tahun 2015 sampai dengan tahun 2019.
3. Berdasarkan hasil perhitungan rasio tunggakan yang diperoleh PT. Adira Dinamika Multi Finance, maka dapat diketahui bahwa rasio tunggakan mengalami ketidakstabilan selama lima tahun yaitu dari tahun 2015 sampai dengan tahun 2019.

4. Berdasarkan hasil perhitungan rasio penagihan yang diperoleh PT. Adira Dinamika Multi Finance, maka dapat diketahui bahwa rasio penagihan mengalami fluktuasi selama lima tahun, Semakin besar rasio penagihan maka akan semakin baik bagi perusahaan dan semakin kecil rasio penagihan maka berakibat buruk bagi perusahaan karena semakin kecil piutang perusahaan yang berubah menjadi kas.

\section{SARAN}

Berdasarkan hasil penelitian dan kesimpulan, maka saran yang dapat diberikan dalam penelitian ini adalah:

1. Sebaiknya pihak perusahaan lebih memperhatikan prosedur penjualan kreditnya agar kesalahan yang dilakukan tidak terulang.

2. Sebelum memberikan piutang alangkah baiknya kalau perusahaan meninjau dengan lebih baik dan teliti tentang lokasi dan pekerjaan calon pelanggan, sehingga dapat memperlancar proses penagihan piutang nantinya.

3. Sistem dan prosedur penjualan kredit perlu diterapkan dengan konsisten, sehingga setiap bagian yang terkait memiliki perhatian dan tanggungjawab pada tugasnya masing-masing. Sebab kesalahan yang dilakukan pada satu bagian dapat mempengaruhi bagian lainnya.

4. Perlu dilakukan pengawasan terhadap sistem akuntansi dan sistem administrasi, karena hal ini dapat 
PAY Jurnal Keuangan dan Perbankan. Vol. 2 No. 2, Desember 2020

mendukung pengendalian yang lebih efektif.

5. Melihat kecenderungan semakin besarnya piutang yang tertunggak dan tidak tertagih, maka periode berikutnya sebaiknya perusahaan meningkatkan kegiatan yang mengarah pada upaya pengembalian piutang tersebut, serta secara serius memperhatikan penjualan kredit agar tetap sesuai prosedur yang ditetapkan.

\section{DAFTAR PUSTAKA}

Agus, Harjito dan Martono. 2007. Manajemen Keuangan. Ekonisia : Yogyakarta.

Alexandri, Moh. Benny. 2009. Manajemen Keuangan Bisnis: Teori dan Soal. Bandung: Penerbit Alfabeta.

Bambang Riyanto, 2003, Dasar-Dasar Pembelanjaan Perusahaan, Edisi keempat Yayasan Penerbit FE UGM, Yogyakarta.

2010. Dasar-Dasar Pembelanjaan Perusahaan, ed. 4 , BPFEYOGYAKARTA.

Baridwan, Zaki, 2004, Intermediate Accounting "Pengantar Akuntansi”, Buku 2, Edisi 21, Salemba Empat. Jakarta.

Charles T.Horngren dan Walter T.Harrison. 2007. Akuntansi jilid Satu. Edisi Tujuh. Jakarta: Penerbit Erlangga.

Hery, 2013. Akuntasi Keuangan Menengah, CPAS, Yogjakarta.
Ikatan Akuntan Indonesia . 2007. Standar Akuntansi Keuangan . Edisi 2007. Penerbit: Salemba Empat . Jakarta .

Kasmir, 2003. Bank dan Lembaga Keuangan Lainnya, PT Raja Grafindo Persada, Jakarta

Kieso, dkk. 2008. Akuntansi Intermediate. Salemba Empat:Jakarta.

$\begin{array}{ll}2009, & \text { Akuntansi } \\ \text { Intermediate. } & \text { Jilid } \quad 1, \\ \text { Erlangga, Jakarta } & \end{array}$

Manulang M., 2005. Dasar-Dasar

Manajemen. Ghalia Indonesia, Jakarta.

Martini, Dwi 2012, Akuntansi Keuangan Menegah Berbasis PSAK. Jilid 1,Salemba Empat, Jakarta.

Mulyadi. 2013. Sistem Akuntansi. Jakarta: Salemba Empat.

Rudianto. 2009. Akuntansi Manajemen. Yogyakarta: Grasindo.

Sappara S., 2019. Analisis Perputaran Piutang pada PT. Prima Karya Manunggal Kabupaten Pangkep. PAY Jurnal Keuangan dan Perbankan, Vol. 1 No. 2, 116-123.

https://ejournals.umma.ac.id /index.php/pay/article/view/ 409.

Soemarso S.R. 2002. Akuntansi Suatu Pengantar, Buku 1, Penerbit Jakarta: Salemba Empat. 
PAY Jurnal Keuangan dan Perbankan. Vol. 2 No. 2, Desember 2020
2004, Akuntansi
Suatu Pengantar, Edisi
Lima, Salemba Empat,
Jakarta.
2009. Akuntansi Suatu
Pengantar, Edisi Kelima,
Penerbit Jakarta: Salemba Empat.

Siagian Adisaputro, 2003. Anggaran

Perusahaan, Edisi 2003/2004, Yogyakarta : BPFE

S. Munawir. 2004. Analisis Laporan Keuangan, Edisi Ke-4, Liberty, Yogyakarta. Ikatan Akuntansi Indonesia (IAI). 2004. Pernyataan Standar Akuntansi Keuangan (PSAK ). Jakarta: Salemba Empat.

Warren Reeve Fess. 2005, “Accounting Pengantar Akuntansi". 21th edition. Salemba Empat Jakarta. 